\title{
Transitional Cell Carcinoma Recurrence in the Nephrostomy Tract After Percutaneous Nephrolithotomy
}

\section{Perkütan Nefrolitotomi Sonrasında Nefrostomi Hattında Transizyonel Hücreli Karsinom Rekürrensi}

\author{
Mustafa Sofikerim', Mert Ali Karadağ², Emrecan Akınsal ${ }^{3}$, Fikret Halis ${ }^{3}$ \\ ${ }^{I}$ Department of Urology, Acıbadem University Faculty of Medicine, Istanbul, Turkey; ${ }^{2}$ Department of Urology, Kafkas University \\ Faculty of Medicine, Kars, Turkey; ${ }^{3}$ Department of Urology, Erciyes University Faculty of Medicine, Kayseri, Turkey
}

\begin{abstract}
Local seeding of the nephrostomy tract has been theorized as a potential risk of percutaneous management of upper urinary tract tumors. Few cases of nephrostomy tract seeding have been reported. We report a case of nephrostomy tract tumor seeding after percutaneous nephrolithotomy.
\end{abstract}

Key words: carcinoma; neoplasm; nephrostomy; percutaneous; seeding; transitional cell

ÖZET

Üst üriner sistem tümörlerinin perkütan yöntemle tedavisinde, nefrostomi hattına tümör ekilmesi potansiyel bir risktir. Literatürde, az sayıda olgu bildirilmiștir. Bu yayında, perkütan nefrolitotomi sonrasında, nefrostomi hattına tümör ekilen bir olgu sunduk.

Anahtar kelimeler: karsinom; neoplazi; nefrostomi; perkütan; ekim; transizyonel hücreli

\section{Introduction}

Transitional cell carcinoma (TCC) of the upper urinary tract often presents a diagnostic and therapeutic challenge. It is relatively uncommon and accounts for $5-10 \%$ of all renal tumors and less than $5 \%$ of all urothelial tumors ${ }^{1}$. The gold standard treatment of upper tract TCC is nephroureterectomy with excision of bladder cuff ${ }^{2}$. However, endoscopic management may be an alternative treatment option in patients with small and low grade tumors and in case where renal sparing surgery is necessary due to a solitary kidney, renal insufficiency or bilateral disease ${ }^{1}$.

Yard. Doç. Dr. Mert Ali Karadă̆, Kafkas Üniversitesi T⿰р Fakültesi, Üroloji Anabilim Dal, Kars, Türkiye, Tel.05325584324Email.karadagmert@yahoo.com

Geliş Tarihi: 28.11.2013 • Kabul Taribi: 20.02.2014
Local tumor seeding of the nephrostomy tract has been theorized as a potential risk of percutaneous management of upper tract tumors and only a few cases of nephrostomy tract seeding have been reported ${ }^{3}$. In this paper, we report a case of nephrostomy tract tumor seeding after percutaneous nephrolithotomy (PCNL) in a patient with stone disease and incidental upper tract TCC.

\section{Case Report}

A 52-year-old male patient was referred to our department with complaints of long lasting left flank pain and intermittent hematuria. Intravenous pyelography (IVP) and urinary tract ultrasound examinations revealed multiple areas compatible with renal stones in middle and lower calyces of the left kidney and grade one hydronephrosis of the ipsilateral kidney. The examination of right side was unremarkable. In addition, there was not any evidence suggesting malignancy.

PCNL was performed in order to remove the renal stones. Intraoperatively, cystoscopic examination was unremarkable. After the removal of the stones, we performed an excisional biopsy of the structure resembling a tumor through the nephroscope, and completed the operation after placing a percutaneous nephrostomy tube. Pathologic evaluation of the biopsy from renal pelvis revealed a transitional cell carcinoma (TCC) and an open nephroureterectomy was performed 14 days after the initial PCNL. Operative specimen was $1.5 \times 2 \mathrm{~cm}$ in diameter and reported as low grade, stage T1N0M0 TCC. Stone type was calcium oxalate monohydrate. Following retrospective assessment, we realized that it was a long standing stone for 10 years. 
Four months after the surgery the patient experienced pain in the left flank incision line. Computerized tomography examination revealed a $2.5 \times 3.1 \mathrm{~cm}$ solid mass between the left flank inferior muscles (Figure 1). We resected the mass with its surrounding muscle tissues (Figure 2). Pathologic evaluation revealed the metastasis of the high grade TCC. Thus, an adjuvant chemo and radiotherapy program was scheduled.. Focal tumors were detected in the urinary bladder at control cystoscopy; thereby, complete transurethral resection and 6 courses of intravesical BCG instillations were performed due to high grade stage T1 TCC in bladder.

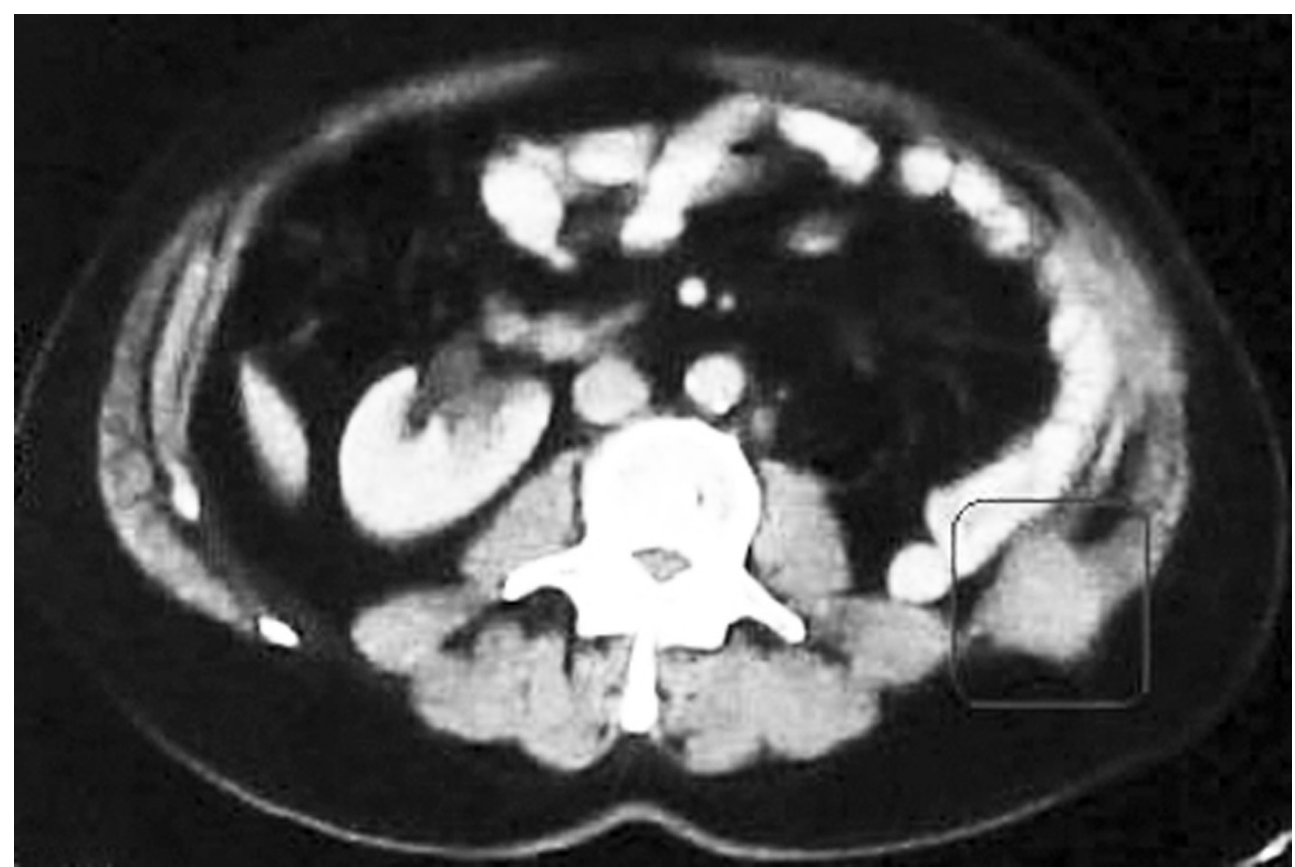

Figure 1. Computerized tomography image of the solid mass between left flank muscles (Surrounded with Blue colour).

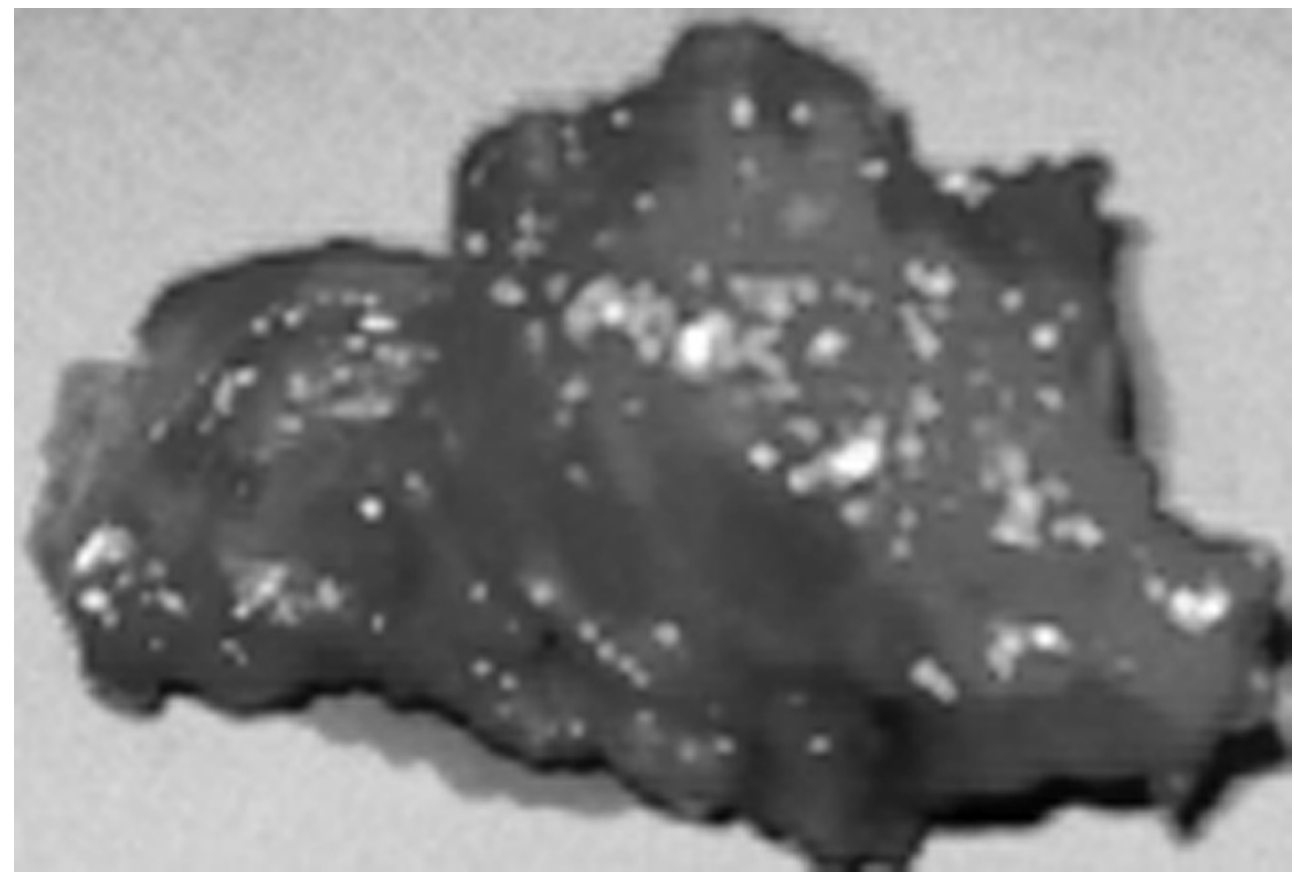

Figure 2. Macroscopic image of the tissue resected from the nephrostomy tract. 
At the sixth month follow up visit, CT examination revealed a $3 \times 3 \mathrm{~cm}$ mass lesion adjacent to spina iliaca anterior superior and multiple metastatic nodules in the lungs. The patient was referred to oncology department for additional chemotherapy and he died following secondary chemotherapy at 18 th month after surgery.

\section{Discussion}

Nephroureterectomy with excision of bladder cuff has been the treatment of choice for upper urinary tract TCC in patients with a normal contra lateral kidney ${ }^{4}$ and the most important prognostic factors are the stage and grade of the tumors 5 . Albeit low-stage and low-grade tumors tend to be associated with good survival after either radical or nephron-sparing surgery ${ }^{6}$, high-grade and high-stage tumors can be controlled in a difficult manner by nephroureterectomy ${ }^{7}$. Although the tumor presented here was a low-grade one, the outcome was poor, probably due to the tumor seeding at the nephrostomy tract.

The discordance between the pathologic grade of the operative specimens (nephrouretercetomy and nephrostomy tract) was re-evaluated in conjunction with the pathologists once again. A dismissed small high grade TCC foci in renal pelvis, ureter or bladder was thought to be an explanation. Actually, bleeding, clots or stone dust observed frequently during PCNL might have obscured the small tumor foci of our patient during the initial evaluation.

Although, we examined the urinary tract using ultrasound and intravenous pyelography prior to the surgery, we did not use contrast enhanced CT scan of the abdomen which would detect the tumor mass in the left renal pelvis.

Endoscopic management of upper urinary tract cancers is an option for patients with low grade/low stage tumors requiring nephron sparing surgery. Successful resection/fulguration of upper tract tumors has been reported with recurrence rates ranging between 0 and $45 \% \mathrm{~s}^{4,8-10}$. Although, the size and stage of the tumor of our patient suggested the choice of endoscopic treatment option, we preferred open nephroureterectomy, as the contra lateral kidney had normal functions.

Tumor seeding in the tract of percutaneous needle aspiration or biopsy has been demonstrated in numerous carcinomas, including prostate, liver, bladder, kidney, gallbladder, and head and neck tumors ${ }^{11-15}$.
However, Tomera et al. reported two cases with local recurrence of transitional cell carcinoma in the renal pelvis, after intraoperative pyeloscopy followed by immediate nephroureterectomy to treat superficial, low grade tumors of the renal pelvis ${ }^{3}$. Although the literature contains a few publication regarding percutaneous tract seeding, our case suggested that endoscopic interventions might result in local recurrence in upper urinary tract TCC's despite low grade and small sized tumors.

Techniques aiming to decrease the risk of access tract seeding have been reported and mostly include the maintenance of a low intrarenal pelvic pressure by using a 30 Fr working sheath and hanging the irrigation solution less than $40 \mathrm{~cm}$ above the level of the patient, use of sterile water as the irrigation solution for its cytolytic effect and resection ${ }^{16}$. Risk may be reduced when endoscopic intervention is performed in a retrograde manner.

The recommended treatment options of TCC following nephroscopic confirmation are nephroureterectomy, adjuvant radiotherapy and immediate resection of the nephrostomy tract ${ }^{17}$. In four patients, Woodhouse et al. prophylactically placed radioactive iridium wires into the nephrostomy tract after percutaneous resection of renal transitional cell carcinoma and none of the patients had tumor cell implantation through the percutaneous tract ${ }^{8}$. We couldn't employ some of these techniques to reduce seeding risk, as we did not have information about tumor existence until nephroscopic examination.

The association of TCC, small cell carcinoma, adenocarcinoma and sarcomatoid carcinoma with renal stone disease has been documented in the literature $^{18-20}$. Urothelial cancer of the renal pelvis in patients undergoing PCNL was studied previously. Of the 500 patients examined during PCNL three patients had urothelial carcinoma of the renal pelvis. The histo-pathological diagnosis was TCC in all cases. In one case the tumor was associated with sarcomatoid features and in another with squamous carcinoma. The overall survival of the three patients was between 2-19 months after the diagnosis of urothelial cancer.

Association of TCC with long standing stone disease has not been studied comprehensively. To our knowledge, the medical literature includes two studies dealing with the relation ${ }^{21,22}$. Kaufmann et al. investigated the effects of long standing catheters and stones on carcinogenesis in patients with spinal cord injuries ${ }^{21}$. 
The authors observed SCC in six patients and TCC in five patients. A similar study including the same kind of patient population reported TCC in six patients and SCC in two patients. However, the concept of the association of renal stones and TCC lacks supporting evidence and needs to be confirmed with more prospective randomized trials.

Long standing calculus may lead to deterioration of renal functions. The pathologic processes identified in a poorly functioning kidney secondary to calculus include chronic pyelonephritis, parenchymal atrophy, xanthogranulomatous pyelonephritis and rarely urothelial carcinomas. Li et al. mentioned that $2 \%$ of their patients with recurrent staghorn calculus had squamous cell carcinoma of the renal pelvis ${ }^{23}$. They also concluded that clinicians should suspect urothelial malignancies in case of a history of long standing stones.

There seems a risk of nephrostomy tract seeding after endoscopic manipulation of urothelial carcinomas of upper urinary tract. Comprehensive preoperative evaluation may lower the risk in patients with renal stones.

\section{References}

1. Huffman JL. Management of upper tract transitional cell carcinomas. Genitourinary oncology 2 nd edition. Philadelphia: Lippincott Williams \& Wilkins; 2000.

2. Mazeman E. Tumors of the upper urinary calyces, renal pelvis and ureter. Eur Urol 1976;2:120-6.

3. Tomera KM, Leary FJ, Zincke H. Pyeloscopy in urothelial tumors. J Urol 1982;127:1088-9.

4. Blute ML, Segura JW, Patterson DE, et al. Impact of endourology on diagnosis and management of upper urinary tract urothelial cancer. J Urol 1989;141:1298-301.

5. Tawfiek ER, Bagley DH. Upper tract transitional cell carcinoma. Urology 1997;50:321-9.

6. Murphy DM, Zinke H, Furlow WL. Primary grade 1 transitional cell carcinoma of the renal pelvis and ureter. J Urol 1980;123:629.

7. Murphy DM, Zinke H, Furlow WL. Management of high grade transitional cell carcinoma of the renal tract. J Urol 1981;125:25.
8. Woodhouse CR, Kellett MJ, Bloom HJ. Percutaneous renal surgery and local radiotherapy in the management of renal pelvic transitional cell carcinoma. Br J Urol 1986;58:245-9.

9. Streem SB, Pontes EJ. Percutaneous management of upper tract transitional cell carcinoma. J Urol 1986;135:773-5.

10. Orihuela E, Smith AD. Percutaneous treatment of transitional cell carcinoma of the upper urinary tract. Urol Clin N Amer 1988; 15:425.

11. Burkholder GV, Kaufman JJ. Local implantation of carcinoma of the prostate with percutaneous needle biopsy. J Urol 1966;95:801-4.

12. John TG, Garden OJ. Needle track seeding of primary and secondary liver carcinoma after percutaneous liver biopsy. HPB Surg 1993;6:199-203.

13. Breul J, Block T, Breidenbach $\mathrm{H}$, et al. Implantation metastasis after a suprapubic catheter in a case of bladder cancer. Eur Urol 1992;22:86-8.

14. Yamakawa T, Itoh S, Hirosawa $\mathrm{K}$, et al. Seeding of gallbladder carcinoma along the tract after percutaneous transhepatic choledochoscopy. Am J Gastroenterol 1983;78:649-51.

15. Huang DT, Thomas G, Wilson WR. Stomal seeding by percutaneous endoscopic gastrostomy in patients with head and neck cancer. Arch Otolaryngol Head Neck Surg 1992;118:6589.

16. Oefelein MG, MacLennan G. Transitional cell carcinoma recurrence in the nephrostomy tract after percutaneous resection. J Urol 2003;170:521.

17. Clark PE, Streem S. Endourologic management of upper tract transitional cell carcinoma. AUA Update Series 1999;18: lesson 16.

18. Katz R, Gofrit ON, Golijanin D, et al. Urothelial cancer of the renal pelvis in percutaneous nephrolithotomy patients. Urol Int 2005;75:17-20.

19. Raghavendran M, Rastogi A, Dubey D, et al. Stones associated renal pelvic malignancies. Indian J Cancer 2003;40:108-12.

20. Jain A, Mittal D, Jindal A, et al. Incidentally detected squamous cell carcinoms of renal pelvis in patients with staghorn calculi: case series with review of the literature. ISRN Oncology 2011;2011:620574.

21. Kaufmann JM, Fam B, Jacobs SC, et al. Bladder cancer and squamous metaplasia in spinal cord injured patients. J Urol 1977;118:967-72.

22. Bickel A, Culkin DJ, Wheeler JS. Bladder cancer in spinal cord injury patients. J Urol 1991;146:1240-4.

23. Li MK, Cheung WL. Squamous cell carcinoma of the renal pelvis. J Urol 1987;138:269-71. 